\title{
Protamine-like proteins' analysis as an emerging biotechnique for cadmium impact assessment on male mollusk Mytilus galloprovincialis (Lamarck 1819)
}

\author{
Marina Piscopo ${ }^{凶}$, Marco Trifuoggi2, Rosaria Notariale1, Sofiane Labar³, Jacopo Troisi, \\ Antonella Giarra2', Dea Rabbito1, Raffaela Puoti', Domenico de Benedictis', Maria Violetta \\ Brundo ${ }^{5}$, Adriana Basile1, Katrina V. Good6, Juan Ausió6 and Giulia Guerriero ${ }^{1,7}$ \\ 1Dipartimento di Biologia, Università degli Studi di Napoli Federico II. Napoli, Italy; ${ }^{2}$ Dipartimento di Scienze Chimiche, Università degli Studi \\ di Napoli Federico II, Napoli, Italy; ${ }^{3}$ Department of Biology, El Tarf University, El Tarf, Algeria; ${ }^{4}$ Theoreo srl-spin-off dell'Università degli Studi di \\ Salerno, 84090 Salerno, Italy; ${ }^{5}$ Dipartimento di Scienze Biologiche, Geologiche ed Ambientali, Università di Catania. Catania, Italy; ${ }^{6}$ Department \\ of Biochemistry \& Microbiology, University of Victoria. Victoria, British Columbia, Canada; 7 Interdepartmental Research Center for Environment \\ (I.R.C.Env.), Università degli Studi di Napoli Federico II. Napoli, Italy
}

Here we report the industrial pollution effects due to cadmium on the reproductive health of Mytilus galloprovincialis. Mussels were removed from the biofouling of a Conatex panel after one year exposition at a polluted site near a disposal metallurgical factory. A high cadmium bioaccumulation was observed in the testis of mussels housed at the polluted site, with respect to a control site, as determined by inductively coupled plasma-mass spectrometry, along with a 10 fold increase in metallothionein $20 \mathrm{kDa}$ gene ( $m t 20)$ expression levels determined by qPCR. Furthermore, mussels transferred into laboratory tanks from the reference site, and exposed to $1.5,5$ and $10 \mu \mathrm{M} \mathrm{CdCl}$, revealed a 1.7, 3.2 and 4.5 fold expression increase in the testis $m t 20$, respectively, and a positive correlation with cadmium bioaccumulation was found. To evaluate a potential detrimental risk of such alterations on spermatozoa, we carried out electrophoretic analyses on their protamine-like proteins. As determined by AU-PAGE, after $1.5 \mu \mathrm{M} \mathrm{CdCl}_{2}$ exposure, protamine-like proteins also display major alterations with respect to those obtained after 5 and $10 \mu \mathrm{M} \mathrm{CdCl}$ exposure. All protamine-like proteins isolated from the polluted biofouling were in an aggregated form and displayed the same reduced DNA binding affinity of the protaminelike proteins obtained after $1.5 \mu \mathrm{M} \mathrm{CdCl}_{2}$ as demonstrated EMSA with sperm genomic DNA. Our results contribute to the studies concerning cadmium induced testis alterations and highlight protamine-like proteins' analysis as an emerging biotechnique for cadmium impact assessment on Mytilus galloprovincialis, for the sensitivity of the in vivo and in vitro changes of protamine-like proteins' state and their DNA binding affinity.

Key words: Mytilus galloprovincialis; cadmium impact assessment; emerging biotechniques; testis metallothionein; Protamine-likeproteins; spermatozoa.

Received: 24 November, 2017; revised: 14 May, 2018; accepted: 28 May, 2018; available on-line: 15 June, 2018

e-mail: piscopo@unina.it

Accession number: 18S rRNA M. galloprovincialis, GeneBank n. Gl: 1008861

mt20 M. galloprovincialis GenBank n AY566247

Abbreviations: PL-proteins, protamine-like proteins; Cd, cadmium; ASW, artificial sea water; ICP-MS, inductively coupled plasma-mass spectrometry; MTs, metallothioneins; ROS, reactive oxygen species; SNBP, sperm nuclear basic proteins; qPCR, real-time quantitative PCR; EMSA, electrophoretic mobility shift assay; MRE, metal response elements; AU-PAGE, urea acetic acid electrophoresis; NIST, National Institute of Standards and Technology Digital Collections, Gaithersburg, MD 20899

\section{INTRODUCTION}

Heavy metals pollution has become one of the most serious environmental problems given their toxicity even at low concentrations and tendency to accumulate in soil, air, water and then entrance into the food chain, bringing detrimental effects onto living organisms, where they can remain for decades (Fasulo et al., 2015; Guerriero et al., 2017; Basile et al., 2017; Conte et al., 2017). Usually, heavy metals can reach the cell nucleus and damage DNA nitrogenous bases because they form reactive oxygen species (ROS) that are highly reactive towards cellular constituents (Piscopo et al., 2018a; Guerriero et al., 2014; Guerriero et al., 2003). Particularly, changes in the levels of ROS can lead to activation or inactivation of transcription factors leading to alterations in the reproductive process (Guerriero et al., 2005; Guerriero et al., 2006; Guerriero 2009; De Maio et al., 2014). Indeed, earlier studies suggested that some heavy metals affect fertility and are associated with abnormal sperm concentration and motility, impaired spermatogenesis, and hormonal imbalance in the exposed organisms (Li et al., 2015). Water pollution by heavy metals can then result in decreased reproductive fitness of many aquatic species leading in some cases to their extinction, with consequent damage to the entire ecosystem (Li et al., 2015).

During the past decades, considerable attention has been focused on heavy metal effects in the aquatic environment (Brady et al., 2015), given that their reproductive toxicity is not limited to adult exposure but can also be due to parental exposure to pollutants in previous periods (Selevan et al., 2000). Among heavy metals, cadmium is one of the most dangerous, being a potent mutagen, highly teratogenic and having a carcinogenic potential demonstrated in bacterial strains and animal models (De Franciscis et al., 2015). A very large amount of cadmium is naturally released into the environment, about 25,000 tons a year, with the ultrastructural alterations effect (Bartiromo et al., 2013). Fifty percent of thus released cadmium is found in rivers through weathering of rocks and a part of it is released into the air through fires and volcanoes. Various human activities, such as manufacturing, contribute to increased cadmium emission into the environment. Anthropogenic input is considered to be the main source of cadmium pollution in aquatic environments (Kalman et al., 2010). Chemical similarity of cadmium to zinc is responsible for its toxi- 
cological effects. In fact, cadmium is able to intercalate between the two strands of DNA, replacing zinc, and can destabilize the DNA helical structure. Breaks in single-stranded DNA and alterations in gene expression are the consequences of this action (Hsiao \& Stapleton et al., 2009). Furthermore, cadmium has a high affinity for DNA bases and causes incorrect DNA synthesis due to mismatched bases. In the literature, the negative impacts of environmental chemicals on male reproductive health are mostly found for rodents and in limited human studies. In this framework for reproductive toxicity studies, invertebrates and lower vertebrates that display similarities to higher organisms are very useful to study negative xenobiotic effects on reproductive processes (Spitsbergen \& Kent et al., 2003). An excellent bioindicator of marine pollution is Mytilus galloprovincialis because it is an organism that is easily available and broadly spread along the Mediterranean. Mussels are in fact an ideal sentinel species as they have an excellent bioaccumulative affinity, as widely documented, and are sensitive to low concentrations of pollutants, including metals (Piscopo et al., 2016). Furthermore, our previous studies highlight a new insight into Mytilus galloprovincialis sperm chromatin organization (Vassalli et al., 2015), whose protein component is mainly constituted by three Protamine-like proteins (PL-proteins): PL-II (20\%), PL-III (50\%) and PL-IV $(6 \%)$, that coexist with about $20 \%$ of somatic histones. PL-proteins are extremely rich in lysine and arginine and belong to sperm nuclear basic proteins (SNBP) that partially or totally replace somatic histones during spermatogenesis. Several field studies have demonstrated that cadmium can accumulate in aquatic invertebrates and can cause an elevation of the intracellular level of metallothioneins (MTs) (Amiard et al., 2006). MTs are cysteine rich low molecular weight proteins, ubiquitous in mollusk species. They bind all metals with high affinity thanks to the thiol groups of the cysteine residues (Amiard et al., 2006), and are involved both, in the homeostatic control of essential metals $(\mathrm{Cu}, \mathrm{Zn})$ and in the organisms' resistance against oxidative stress, having also a role in detoxification of non-essential trace metals, including cadmium. In mussels, the characterized MTs include the families of the monomeric and dimeric metallothionein isoforms (Mackey et al., 1993), MT10 and MT20 isoforms, respectively, which can perform different functions and may be differentially regulated in a tissue- and/or cell-specific way in the presence of different metals and stressors. MT10s are synthesized in a constitutive way and are involved in regulation of essential metals, in particular $\mathrm{Cu}$ and Zn, while MT20s are inducible and are mainly involved in $\mathrm{Cd}$ and hydroxyl radical detoxification (Dondero et al., 2005). The metallothionein $10 \mathrm{kDa}(m+10)$ gene is highly expressed at a basal level and can respond to both, essential $(\mathrm{Cu}, \mathrm{Zn})$ and nonessential (Cd, Hg) heavy metals (Dondero et al., 2005). Conversely, $m+20$ appear to be rarely transcribed with a very low basal expression level (few copies per cell) but, particularly in the presence of $\mathrm{Cd}$, their expression could be considerably activated, up to a thousand fold. This MT's gene expression regulation is highly complex since a variety of regulatory elements have been identified in their promoter regions (Vergani et al., 2007).

For pollution biomonitoring, MTs have been used as biomarkers of metal contamination in various species (Dondero et al., 2005; Ladhar-Chaabouni et al., 2012). There are many reports in the literature which assess the effect of various xenobiotics on DNA fragmentation, sperm count, sperm motility, and sperm morphology. Most of these studies concluded that pollution affects at least one of these four semen quality parameters, but in many cases the results of these studies were not comparable. In order to provide new insight into assessment of xenobiotic impact on the testis and spermatozoa, in this work we have analyzed the effects of industrial pollution and cadmium exposure on the reproductive health of the male Mediterranean mussel, Mytilus galloprovincialis. Recently, we have reported results of the reproductive health monitoring studies in Mytilus galloprovincialis following spermatozoa hsp70 expression and PL-proteins' properties. In particular, we found alterations in the PLproteins' electrophoretic pattern and in their DNA binding mode and affinity (Piscopo et al., 2018b). Thus, in this work we studied industrial pollution by using mussels removed from the biofouling of a Conatex panel after one year of exposition when the panel is completely covered only by mussels, at a polluted site close to a disposal metallurgical factory: Ilva in Bagnoli (Naples, Campania - Italy). Because Bagnoli mussels' testis revealed a high cadmium bioaccumulation and cadmium also poses a risk to fertility (Mathur et al., 2010; Simoniello et al., 2013), we further investigated the specific effects of cadmium on mussels exposed to laboratory tanks containing different $\mathrm{CdCl}_{2}$ concentrations. We analyzed the $m+20$ gene expression levels both, in the testis of Bagnoli biofouling mussels and in those of mussels exposed to laboratory tanks. Furthermore, we evaluated the state of PL-proteins of the Bagnoli mussels and their DNA binding affinity, as well as changes in the control mussels exposed to $1.5,5$ and $10 \mu \mathrm{M} \mathrm{CdCl}{ }_{2}$ concentrations.

\section{MATERIALS AND METHODS}

Ethics Statement. The research described herein was performed on the marine invertebrate Mytilus galloprovincialis (Lamarck, 1819), which is not protected by any environmental agency in Italy. This study was conducted in strict accordance with European (Directive 2010/63) and Italian (Decreto Legislativo n. 116/1992) legislation on the care and use of animals for scientific purposes.

Study area, mussel samplings, treatments, testes and gametes processing. Mussels Mytilus galloprovincialis (5.2 $\pm 0.4 \mathrm{~cm}$ shell length) were collected in June 2016 from the biofouling Conatex panels, after one year of exposition in the industrial areas of Bagnoli (Campania; South Italy) and the reference site, Capo Miseno. Samples were collected in areas at different degrees of pollution after previous characterization of the sites (Scalici et al., 2017).

To investigate the specific effects of cadmium biofouling, mussels from the reference site of mixed sex were also exposed to $1.5,5$ and $10 \mu \mathrm{M} \mathrm{CdCl}$ in laboratory tanks $\left(30 \times 40 \times 60 \mathrm{~cm}, 7 \mathrm{~L}\right.$ volume). The $\mathrm{CdCl}_{2}$ concentration gradient used for mussel exposure in tanks was designed choosing three $\mathrm{CdCl}_{2}$ concentrations; 1.5 and $5 \mu \mathrm{M}$ fall within the limits of survival for estuarine/ marine invertebrate aquatic life, while $10 \mu \mathrm{M}$ fall within chronic toxicity (Aquatic Life Ambient Water Quality Criteria - Cadmium 2016 - EPA). In particular, 10 mussels were placed in $4 \mathrm{~L}$ of artificial sea water (ASW;) $32 \%$ salinity), for $24 \mathrm{~h}$ at $18^{\circ} \mathrm{C}$ in tanks containing only ASW (unexposed group) or ASW containing $\mathrm{CdCl}_{2}$ (exposed group). Water and metal salts were changed every $12 \mathrm{~h}$ during treatment. For each system, dissolved oxygen and temperature were recorded at predetermined time intervals. Mussels were sexed by examining gametes under a light microscope. Testes emptied of gametes were rapidly frozen in liquid nitrogen and stored 
at $-80^{\circ} \mathrm{C}$ until molecular and biochemical assessment. Spermatozoa were taken from each testis (Skibinski et al., 1994), incubated in a glass of seawater for 20 minutes and then collected in pellets $(200 \mathrm{mg}$ ) by centrifugation at $9000 \times \mathrm{g}$ for 10 minutes at $4^{\circ} \mathrm{C}$.

Cadmium bioaccumulation analysis by inductively coupled plasma-mass spectrometry. The analyses were performed on tissues derived from 5 pools of three mussels each from field experiments, and 2 pools of three mussels each from laboratory tanks. DigiBlock sample preparation system (LabTech, MA, USA) was used for samples digestion. Samples of about \pm 0.1000 $\mathrm{g}$ were placed in a Teflon vessel and digestion was carried out with $10 \mathrm{ml}$ of Optima-grade Nitric acid $\left(\mathrm{HNO}_{3}\right)$ and $3 \mathrm{ml}$ of $30 \%$ Optima $\mathrm{H}_{2} \mathrm{O}_{2}$. Samples were reconstituted to $10 \mathrm{~mL}$ of $18.2 \mathrm{MX} \mathrm{cm}^{2} 25^{\circ} \mathrm{C}_{2} \mathrm{O}$ with $2 \%$ nitric acid (both optima-grade). A quadruple inductively coupled plasma-mass spectrometry, ICP-MS (820MS, Bruker) was used for metal quantification with calibration solutions from multi-elemental standard stock solutions (9 calibration solutions) of $20.00 \mathrm{mg} / \mathrm{L}$. In order to verify reagent purity and laboratory equipment, reagent blanks containing ultra-pure water were also analyzed. A mix solution of internal standard $(6 \mathrm{Li}, 45 \mathrm{Sc}, 72 \mathrm{Ge}, 89 \mathrm{Y}$, $103 \mathrm{Rh}, 159 \mathrm{~Tb}, 165 \mathrm{Ho}, 209 \mathrm{Bi})$ at $10 \mathrm{mg} / \mathrm{L}$, was on-line aspired with a $\mathrm{T}$ union with the sample and standard solution was used for the analyses along with a blank sample; at least 2 standard samples were analyzed every 10 samples, in order to verify the instrument calibration constants. To control the accuracy of analysis, a certified reference of NIST bovine liver was analyzed before and after each session of analysis.

Real-time quantitative PCR. Total RNA was purified from individual testes samples using the Trizol reagent (Invitrogen) according to the manufacturer's instructions. Analyses were made with 5 pools of three biofouling mussels each from the field experiments, and 2 pools of three mussels each from the laboratory tank experiments. The quantification and quality of RNA samples were controlled with a UV-Vis spectrophotometer (NanoDropH ND-1000) and by 1\% agarose gel electrophoretic analysis under denaturing conditions (Rave et al., 1979). Equal amounts of RNA obtained from the testis tissue from Bagnoli biofouling mussels; Capo Miseno biofouling mussels (control) and from mussels exposed to specific $\mathrm{CdCl}_{2}$ concentration in laboratory tanks, were used in qPCR analyses. Before retrotranscription, which we performed with M-MLV reverse transcriptase (ImpProm II kit, Promega), we purified the RNA samples from genomic DNA with an Ambion DNA-free kit. $9 \mu \mathrm{g}$ of RNA from each pooled sample were used to perform 3 independent cDNA syntheses using random hexamers $(0.5 \mu \mathrm{g} / \mu \mathrm{g}$ RNA). For the determination of mt20 expression by real-time PCR, cDNA was diluted $1: 3$ and we used $0.5 \mathrm{mM}$ of each forward and reverse primers in a final volume of $25 \mu \mathrm{l}$ using SYBR Green PCR Master Mix Kit (Applied Biosystems) with the 7500 Real Time PCR System (Applied Biosystems). The conditions of qPCR were as follows: $50^{\circ} \mathrm{C}$ for $2 \mathrm{~min}$; $10 \mathrm{~min}$ at $95^{\circ} \mathrm{C}$, followed by 40 cycles of $95^{\circ} \mathrm{C}$ for $15 \mathrm{~s}$ and $55^{\circ} \mathrm{C}$ for $1 \mathrm{~min}$ and then $95^{\circ} \mathrm{C}$ for $15 \mathrm{~s} .18 \mathrm{~S}$ rRNA was used as the internal reference. Open source software Primer3 was used for the design of the primers for $18 \mathrm{~S}$ rRNA (18S rRNA primers F/R: GCCACACGAGATTGAGCAAT/CTCGCGCTTACTGGGAATTC; $18 \mathrm{~S}$ rRNA M. galloprovincialis, GeneBank n ${ }^{\circ}$. GI: 1008861 and L33451.1.), while for the determination of $m+20$ expression we used the following primers MT-20 F/R: GTGAAAGTGGCTGCGGA/GTACAGCCACATCCA-
CACGC GenBank n AY566247 as reported in Sureda et al., (2011). Before real-time PCR, we verified by PCR that each primer pair produced a single primary amplicon. qPCR product dissociation curves for all transcripts gave single peaks. To determine relative gene expression values, we used the $\Delta \Delta \mathrm{Ct}$ method (Livak \& Schmittgen et al., 2001). The expression levels of the $18 \mathrm{~S}$ ribosomal gene were essentially stable as also reported by other authors (Dondero et al., 2005). All samples and the internal reference were run and amplified in triplicate. We measured change in expression of $m+20$ transcripts relative to the reference 18S rRNA in the testes samples from mussels of Bagnoli biofouling or those exposed to cadmium in comparison to control mussels of the reference site of Capo Miseno.

Protein extraction from Mytilus galloprovincialis spermatozoa. Extraction of Mytilus galloprovincialis protamine-like proteins from spermatozoa was performed with $5 \%$ perchloric acid; $n=10$ spermatozoa pellets were resuspended in $15 \mathrm{~mL}$ of distilled water and homogenized with a potter and then perchloric acid was added. Acid extraction was performed as described by Vassalli and coworkers (Vassalli et al., 2015), taking care at the end of procedure to extensively dialyze the samples containing PCA soluble PL-proteins against distilled water, in order to ensure all PCA was removed. Finally, the samples were lyophilized and stored at $-80^{\circ} \mathrm{C}$.

Electrophoretic Analysis of Mytilus galloprovincialis PL-proteins. The state of sperm proteins was analyzed by: A) Urea acetic acid Electrophoresis (AUPAGE) as described by Salvati and coworkers (Salvati et al., 2008), B) SDS-PAGE: Gels were run in vertical slab gel units (Mini Protean Biorad). A ratio of 30:0.15 of acrylamide: bisacrylamide was used. Stacking gels contained $5.0 \%$ (w/v) acrylamide, e $125 \mathrm{mM}$ Tris $\mathrm{pH} 6.8$, $0.1 \%(\mathrm{w} / \mathrm{v})$ SDS, $0.025 \%(\mathrm{w} / \mathrm{v})$ ammonium persulfate (APS), and $0.025 \%(\mathrm{v} / \mathrm{v})$ TEMED, while Separating gels contained $18.0 \%$ (w/v) acrylamide, $750 \mathrm{mM}$ Tris $\mathrm{pH} 8.8$, $0.1 \%(\mathrm{w} / \mathrm{v}) \mathrm{SDS}, 0.025 \% \mathrm{APS}$, and $0.025 \%$ TEMED. Samples were loaded with previous boiling. The electrode buffer was prepared by mixing $0.38 \mathrm{M}$ glycine, $0.05 \mathrm{M}$ Tris and $0.1 \%(\mathrm{w} / \mathrm{v})$ SDS. Gels $(83 \times 58 \times 0.75$ $\mathrm{mm})$ were run for 70 minutes at $100 \mathrm{~V}$. Gels were fixed with $30 \%$ methanol and $10 \%$ acetic acid, and stained using $0.2 \%$ Coomassie Brilliant Blue, 30\% methanol, and $10 \%$ acetic acid; the gels were destained with $30 \%$ methanol and 10\% acetic acid.

Sperm DNA extraction. Sperm DNA, used for EMSA, was obtained as follows: a pellet of spermatozoa of about $200 \mu \mathrm{L}$ was suspended in $500 \mu \mathrm{L}$ of $2 \mathrm{X}$ lysis buffer with the following composition: $20 \mathrm{mM}$ Tris-HCl, pH 8.0; 20 mM EDTA, pH 8.0; $200 \mathrm{mM} \mathrm{NaCl}, 4 \%$ SDS, $20 \mu \mathrm{g} / \mathrm{mL}$ Proteinase $\mathrm{K}$, and incubated at $37^{\circ} \mathrm{C}$ for 30 minutes. After centrifugation at $15000 \mathrm{rpm}$ for 15 ' at $4^{\circ} \mathrm{C}$, the obtained pellet was washed with $1 \mathrm{X}$ lysis buffer and then centrifuged once again under the same conditions. The obtained pellet was suspended in $1 \mathrm{X}$ lysis buffer containing $39 \mathrm{mM}$ DTT and kept overnight at $37^{\circ} \mathrm{C}$. DNA was obtained using phenol/chloroform extraction followed by ethanol precipitation. Purified DNA was suspended in a TE buffer (1 mM EDTA, $0.01 \mathrm{M}$ Tris-HCl, pH 8.0).

Plasmid DNA preparation and analysis. pGEM3 plasmid DNA, in a circular form, that was used for EMSA was prepared according to Carbone and coworkers (Carbone et al., 2012) and analyzed by gel electrophoresis on $1 \%$ agarose gels in $89 \mathrm{mM}$ Tris- $\mathrm{HCl}, \mathrm{pH} 8.0$, $2 \mathrm{mM}$ EDTA, and $89 \mathrm{mM}$ boric acid (TBE). 
Analysis of the effect of Mytilus galloprovincialis PL-proteins on DNA electrophoretic mobility. DNA binding affinity of PL-proteins was evaluated by performing Electrophoretic Mobility Shift Assay (EMSA) and analyzing the results on $1 \%$ agarose gels using $1 \mu \mathrm{g}$ of pGEM3 plasmid DNA or sperm genomic DNA; the latter was extracted from spermatozoa of mussels of the Capo Miseno reference site, and increasing amounts of proteins were expressed as protein/DNA w/w ratios. The amounts of Mytilus galloprovincialis PL-proteins reported on the wells of the gels shown in the results section were added to $1 \mu \mathrm{g}$ of genomic DNA or to pGEM3 plasmid DNA in a final volume of $30 \mu \mathrm{L}$ containing $1 \mathrm{X}$ TBE. All mixtures of DNA-PL-proteins were incubated for 10 minutes at $16^{\circ} \mathrm{C}$ before their analysis on $1 \%$ agarose gels in TBE. DNA migration was visualized by staining gels with ethidium bromide $(2 \mu \mathrm{g} / \mathrm{mL})$ after electrophoresis.

Statistical analysis. Multiple group data were analyzed using one-way ANOVA. The Student's $t$-test was used to compare means between the groups. Values were considered significant when $p<0.05$. Statistically significant differences are defined at the $95 \%$ confidence interval. Data are shown as mean \pm S.D.

\section{RESULTS AND DISCUSSION}

Figure 1 shows the results of cadmium bioaccumulation in testes of Mytilus galloprovincialis specimens of Bagnoli and Capo Miseno biofouling and after exposure for $24 \mathrm{hrs}$ to $1.5,5$ and $10 \mu \mathrm{M} \mathrm{CdCl}$ in laboratory tanks.

The analyses performed by ICP-MS show that cadmium content of the mussel testes ranges from $0.066 \pm 0.007 \mathrm{mg} / \mathrm{kg}$ at the reference site, Capo Miseno to $4.172 \pm 0.209 \mathrm{mg} / \mathrm{kg}$ at Bagnoli.

Observation of such high levels of cadmium in the testes of Mytilus galloprovincialis specimens from Bagnoli biofouling prompted us to perform a study to assess the effects of this metal on mussel reproductive fitness, since detrimental effects of this metal on reproduction and development in a variety of different models have been detected (Thompson \& Bannigan, 2008). First, we determined the bioaccumulation of this metal in testes of Mytilus galloprovincialis exposed for 24 hrs to 1.5, 5 and $10 \mu \mathrm{M} \mathrm{CdCl}$ in laboratory tanks (Fig. 1). The analyses showed that cadmium bioaccumulation generated an increasing linear trend with the exposition dose within the range tested $(1.5-10 \mu \mathrm{M})$. In particular, cadmium content of mussels' testes ranges from $0.066 \pm 0.0015 \mathrm{mg} /$ $\mathrm{kg}$ in the unexposed mussels, to $0.21 \pm 0.013 \mathrm{mg} / \mathrm{kg}$, $0.34 \pm 0.015 \mathrm{mg} / \mathrm{kg}$ and $0.82 \pm 0.0230 \mathrm{mg} / \mathrm{kg}$ for $1.5,5$ and $10 \mu \mathrm{M}$ exposure, respectively. The results obtained for the exposure of mussels to $\mathrm{CdCl}_{2}$ in laboratory tanks also showed that the low $\mathrm{CdCl}_{2}$ concentrations induced a response to this metal in the testes, indicative of germ line stress. It is well known that reproductive tissues and organs react to oxidative stress by synthesis of stress proteins, such as metallothioneins. Due to their inducibility upon metal exposure, over the past 20 years MTs have been widely adopted as biomarkers for monitoring metal contamination in aquatic ecosystems, both at the protein (Ladahar-Chaabouni et al., 2012) and transcript levels (Vergani et al., 2007). OSPAR (Oslo-Paris convention for the Protection of the Marine Environment of the North-East Atlantic), UNEP/MAP (United Nations Environment Programme/Mediterranean Action Plan) and Mussel Watch Programme are the most famous biomonitoring programs in which MTs were used. In Myti-

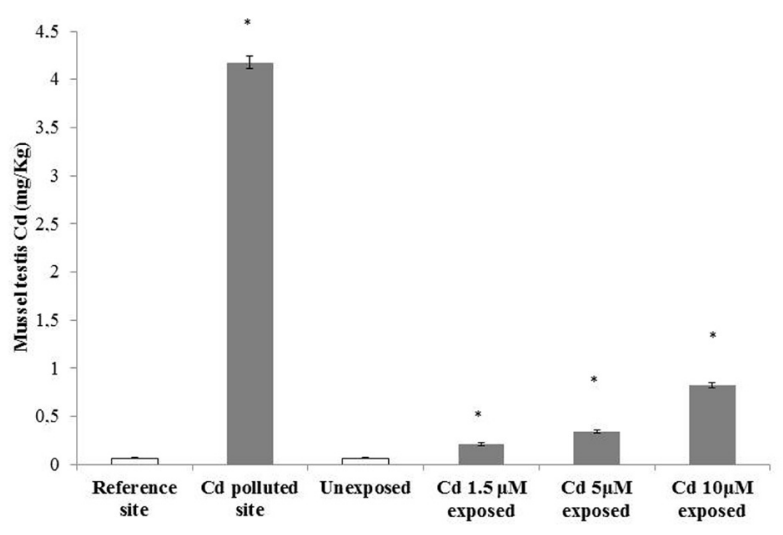

Figure 1. ICP-MS analyses of cadmium bioaccumulation in testes of Mytilus galloprovincialis

Cadmium bioaccumulation in testes of Mytilus galloprovincialis specimens from Capo Miseno, reference site; Bagnoli, Cd polluted site, biofouling panels and in Capo Miseno Mytilus galloprovincialis specimens unexposed and exposed to $1.5,5$ and $10 \mu \mathrm{M} \mathrm{CdCl}_{2}$ in laboratory tanks. The values are expressed based on the wet weight basis. All values represent the mean \pm S.D. obtained from 5 pools of three mussels each of the field experiments, and the mean \pm S.D. obtained from 2 pools of three mussels each of the laboratory tank experiments; asterisks indicate a statistically significant difference $(p<0.05)$ when compared to Capo Miseno biofouling mussels and unexposed mussels

lus edulis (Mackey et al., 1993), Mytilus galloprovincialis (Vergani et al., 2007), Batbymodiolus azoricus, and Batbymodiolus thermophilus mussels (Hardivillier et al., 2004), there are described two types of MT isoforms, MT10 and MT20. Metal response elements (MRE) in the proximal promoters of MT genes are responsible for heavy metal-induced MT gene transcription. These elements mediate the transcriptional response of MT to $\mathrm{Zn}, \mathrm{Cd}$, oxidative stress, and to hypoxia (Hardivillier et al., 2004). Since the $m t 20$ gene is dramatically responsive to cadmium (Dondero et al., 2005), we focused our attention on the expression level of this gene in the testes of mussels from the Bagnoli biofouling and mussels exposed to $1.5,5$ and $10 \mu \mathrm{M}$ $\mathrm{CdCl}_{2}$ under laboratory conditions. Expression of $m+20$ transcripts was evaluated by real-time quantitative PCR (qPCR), using $18 \mathrm{~S}$ rRNA as a reference gene for data normalization. In fig 2 the results obtained by qPCR are shown which indicate cadmium induced $m+20$ gene expression in Mytilus galloprovincialis testes. The mt20 expression levels in the testes of mussel from Bagnoli biofouling panel and in testes of mussels exposed to $\mathrm{CdCl}_{2}$ were higher when compared to those of Capo Miseno biofouling mussels at the reference site. As a matter of fact, exposure of mussels to $1.5,5$ and $10 \mu \mathrm{M} \mathrm{CdCl}_{2}$ under laboratory conditions results in 1.7, 3.2 and 4.5 fold increases in $m+20$ expression, respectively; while a 10 fold increase of the testes $m+20$ expression was observed in mussels from Bagnoli biofouling panel when compared to unexposed Capo Miseno mussels (Fig. 2). Metallothioneins play a fundamental role in the accumulation of cadmium; in fact, their expression has been reported in Mytilus edulis and Mytilus galloprovincialis gills, hepatopancreas, digestive gland, mantle and kidney following exposure to this metal (Vergani et al., 2007). Our results are in agreement with those reported in other mussel tissues (Ladhar-Chaabouni et al., 2012), with those published on zebra mussel gills (Vincent-Hubert et al., 2014) and in the testes of the Boleophthalmus pectinirostris mudskipper (Han et al., 2015) and Pseudosciaena crocea croaker (Sheng et al., 2015); also, in many cases the cadmium exposure dose was higher with respect to our conditions in labo- 


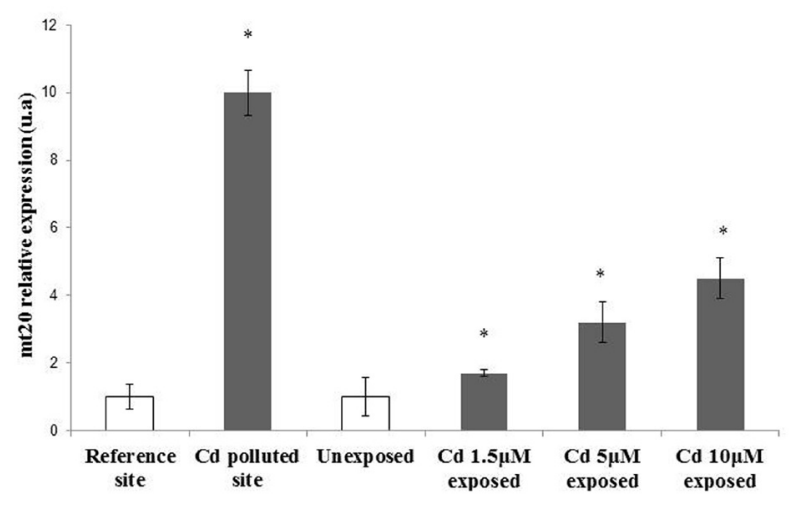

Figure 2. q-PCR expression analysis of the Mytilus galloprovincialis testes $m t 20$

The relative expression of $m t 20$ indicated as arbitrary units (u.a.) means the change in expression of the transcripts of $m t 20$ gene in comparison to the reference housekeeping 185 gene. For field experiments, samples are from Capo Miseno, reference site, and Bagnoli, Cd polluted site. All values represent the mean \pm S.D. obtained from 5 pools of three mussels each. For laboratory tank experiments, Capo Miseno mussels were unexposed and exposed to $1.5,5$ and $10 \mu \mathrm{M} \mathrm{CdCl}_{2}$; all values represent the mean \pm S.D. obtained from 2 pools of three mussels each. Asterisks indicate a statistically significant difference $(p<0.05)$ compared to Capo Miseno mussels (in field experiments) and unexposed Capo Miseno mussels (laboratory tanks experiments).

ratory tanks. The relatively higher testis $m+20$ expression level observed in mussels from Bagnoli biofouling compared to Capo Miseno mussels exposed to cadmium in laboratory tanks reflects the higher cadmium amount in Bagnoli and the differences in the treatment duration. We have also determined the correlation between cadmium bioaccumulation and $m+20$ expression in testes from Capo Miseno mussels exposed to this metal in laboratory tanks. We found that in testes, the metal bioaccumulation exhibits an excellent correlation, in the concentration range tested, with a value of $\mathrm{R} 2$ determination coefficient of 0.9867 (Fig. 3). These results add insight to the inducibility of Mytilus galloprovincialis stress genes by cadmium, also at non-lethal levels. In fact, we have recently reported (Piscopo et al., 2017) the occurrence of gill hsp70 response to cadmium in the same range of

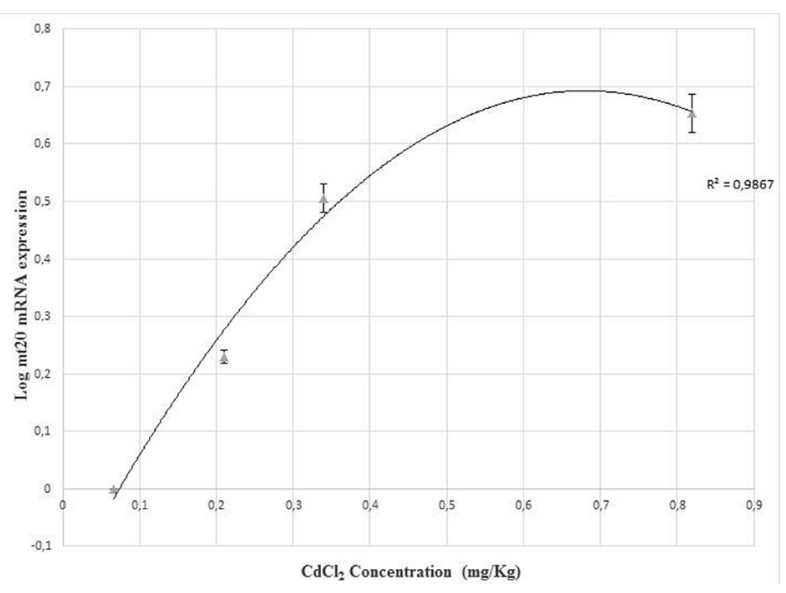

Figure 3. Correlation between cadmium bioaccumulation and mt20 testis expression

Correlation between cadmium bioaccumulation in testis of mussels of the reference site, Capo Miseno, and exposed to 1.5, 5 and $10 \mu \mathrm{M} \mathrm{CdCl}_{2}$ in laboratory tanks with $m t 20$ testis expression (log transformed). concentrations used as in this work. Indeed, a positive correlation was observed between cadmium concentration in gills of Mytilus galloprovincialis and hsp70 expression.

Many papers have been published on the effects of cadmium on gametogenesis in both, males and females, which have shown that a wide range of anomalies can be caused at specific stages of embryogenesis following exposure, and several studies have indicated that cadmium may also be related to pathological processes in the late pregnancy and in the early postnatal period (Mathur et al., 2010; Rzymski et al., 2015; Wirth \& Mijal et al., 2010). Contributions from the sperm and ovum are critical for successful reproduction which is essential for the maintenance of life. Oxidative stress affects sperm function and is an important cause of male infertility, and cadmium is an occupational and environmental reproductive toxic agent to which humans are exposed and which can have negative effects on the sperm chromatin DNA integrity (Guerriero et al., 2014; Wirth \& Mijal et al., 2010). There are several reports on the reproductive toxicity of cadmium. Cadmium, by way of causing an excessive production of ROS, fatty acid peroxidation, apoptosis and Sertoli cell damage, has several negative effects on the reproductive system. Cadmium also interrupts oocyte development in numerous species, such as Xenopus laevis, hamsters, rats, mice, pigs and sheep (Thompson \& Bannigan, 2008). Also, for human sperm there are reported various negative effects induced by cadmium, such as decreased spermatozoa counts per ejaculate and volume, and alterated spermatozoa forms (Wirth \& Mijal, 2010). Although all these adverse consequences are reported, until 2018 the literature lacked information regarding the effects of cadmium on spermatozoa proteins and on their DNA binding affinity. Recently, we have published the results of our studies regarding the effects on reproductive health in Mytilus galloprovincialis housed in Bagnoli by following spermatozoa hsp70 expression and PL-proteins' properties. Specifically, we showed alterations in the electrophoretic pattern of the PL-proteins and in their DNA binding mode and affinity (Piscopo et al., 2018b). Since in Bagnoli mussel testes we found that cadmium bioaccumulation was higher with respect to that in the mussel testes of the reference site (Fig. 1), in this section we analyzed the state of PL-proteins through two in vivo systems, with Mytilus galloprovincialis removed from biofouling panels of cadmium polluted and unpolluted sites, and exposed and unexposed to cadmium in experimental tanks. In this work, samples were also collected at other locations with different degrees of pollution which was discovered after characterization of the sites (Scalici et al., 2017), but we only report the results relative to Bagnoli and Capo Miseno in relation to the number of mussels examined and to the significance of the results obtained. The levels of the analyzed markers showed no intra-site change and the response to the environmental insult was univocal for each of the sites examined (Piscopo et al., 2018).

Figure 4 shows a comparative analysis of the electrophoretic pattern, by AU-PAGE, of Mytilus galloprovincialis PLs extracted from spermatozoa of mussels exposed to the three different concentrations of $\mathrm{CdCl}_{2}$ in laboratory tanks, in comparison to those of unexposed mussels derived from the reference site. Comparison between the PL-proteins extracted from spermatozoa of mussels of the reference site (lane 1), from spermatozoa of mussels exposed to $5 \mu \mathrm{M} \mathrm{CdCl}$ (lane 2) and from spermatozoa of mussels exposed to $1.5 \mu \mathrm{M} \mathrm{CdCl}_{2}$ (lane 3) are shown in panel A. From this first electrophoretic analysis it is 
A

B

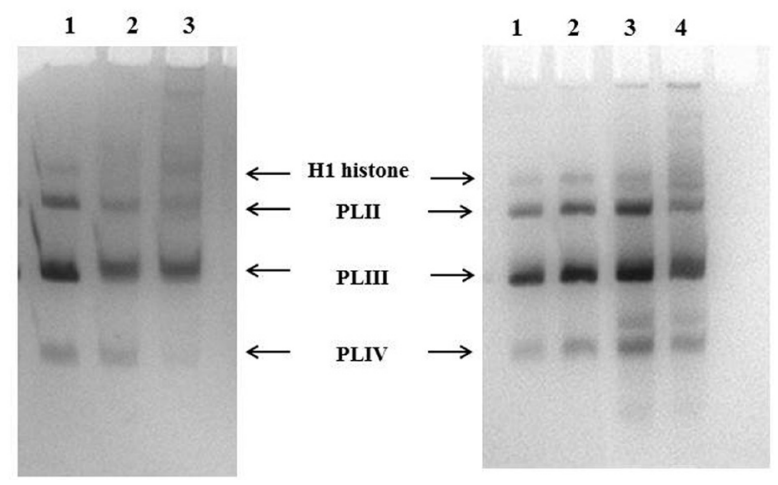

Figure 4. Electrophoretic analyses by AU-PAGE of PL-proteins of Mytilus galloprovincialis exposed to different concentrations of $\mathrm{CdCl} 2$

AU-PAGE of PL-proteins extracted from Mytilus galloprovincialis spermatozoa of (A) 1. Capo Miseno, reference site; 2. exposure to $5 \mu \mathrm{M} \mathrm{CdCl}$, 3. exposure to $1.5 \mu \mathrm{M} \mathrm{CdCl}_{2}$ (B) 1. Capo Miseno, reference site; 2 . exposure to $10 \mu \mathrm{M} \mathrm{CdCl}_{2 ;} 3$. exposure to $5 \mu \mathrm{M} \mathrm{CdCl}_{2 \text {; }}$ 4. exposure to $1.5 \mu \mathrm{M} \mathrm{CdCl}_{2}$
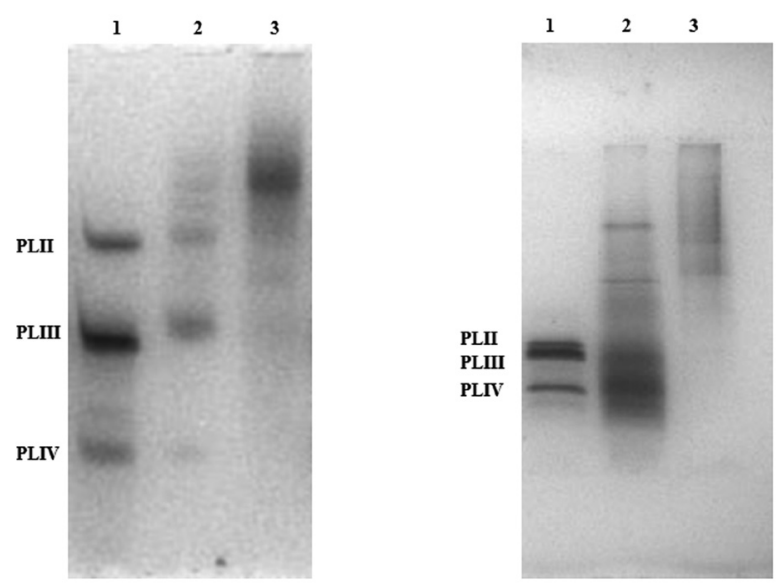

Figure 5. Electrophoretic analyses of Mytilus galloprovincialis PLproteins

AU-PAGE (left) and SDS PAGE (right) of PL-proteins extracted from Mytilus galloprovincialis spermatozoa of $\mathbf{1}$. Capo Miseno, reference site; 2. exposed to $1.5 \mu \mathrm{M} \mathrm{CdCl}$ 3. Bagnoli, Cd polluted site

evident that the sample pertaining to exposure to $1.5 \mu \mathrm{M}$ $\mathrm{CdCl}_{2}$ (lane 3 ) is more altered because the PL-proteins appear in part to be in an aggregated form. This behavior also occurs in the sample exposed to $5 \mu \mathrm{M} \mathrm{CdCl}$ (lane 2) but in a less pronounced manner. Comparison between the PL extracted from spermatozoa of mussels of the reference site (lane 1), to spermatozoa of mussels exposed to $10 \mu \mathrm{M} \mathrm{CdCl}$ (lane 2), $5 \mu \mathrm{M} \mathrm{CdCl}$ (lane 3) and $1.5 \mu \mathrm{M} \mathrm{CdCl}$ (lane 4 ) is shown in panel $\mathrm{B}$. In this case, we overloaded the samples for a better visualization of the differences between the three samples. Overloading the samples allowed us to observe that PL-II and PL-III appear as a highly pure single band. In contrast, several subcomponents are present in the region of the gel corresponding to PL-IV and reflect the microheterogeneity of this protein, as previously described by Ausiò and Subirana (Ausiò \& Subirana, 1982), similar to what is observed for other conventional protamines (Ausiò \& McParland, 1989). Moreover, it is reported that $8 \%$ of serines are phosphorylated in PL-IV (Ausiò \& Subirana, 1982) which could additionally contribute to some

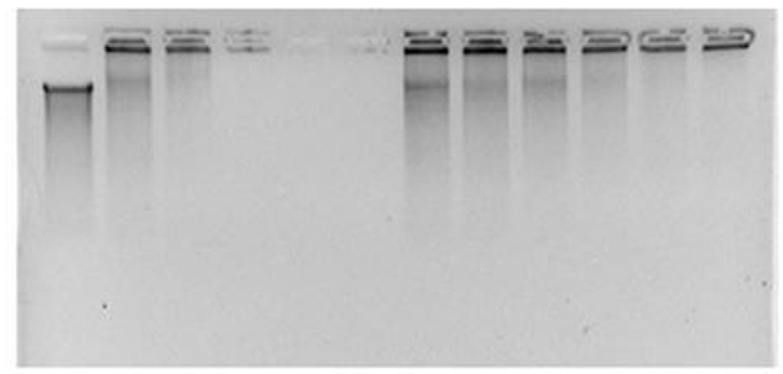

Figure 6. EMSA analyses of DNA binding affinity of PL-proteins from reference site and $\mathrm{Cd}$ polluted site mussels using sperm genomic DNA

EMSA analyses of DNA binding affinity of PL-proteins from Mytilus galloprovincialis of Capo Miseno, reference site, and Bagnoli, Cd polluted site. Numbers on the wells indicate the PL-proteins/DNA (w/w) ratios used; DNA denotes Mytilus galloprovincialis sperm genomic DNA with no proteins added.

\section{Unexposed}

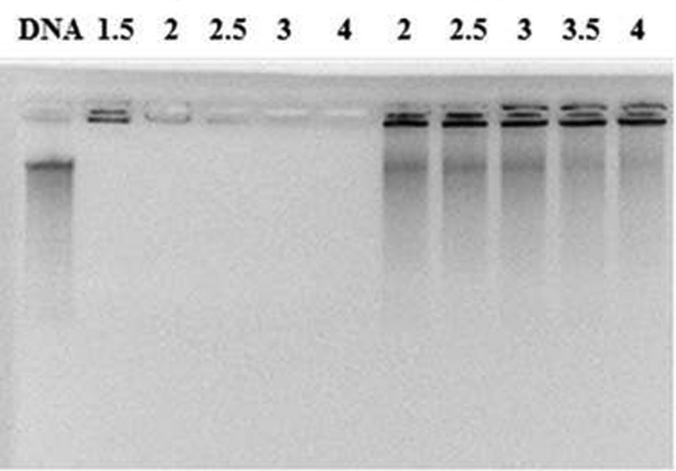

Figure 7. EMSA analyses of DNA binding affinity of PL-proteins from unexposed and $1.5 \mu \mathrm{M} \mathrm{CdCl}_{2}$ exposed mussels using sperm genomic DNA

EMSA analysis of DNA binding affinity of PL-proteins from Mytilus galloprovincialis spermatozoa unexposed and exposed to $1.5 \mu \mathrm{M}$ $\mathrm{CdCl}_{2}$. Numbers on the wells indicate the PL-protein/DNA (w/w) ratios used; DNA denotes Mytilus galloprovincialis spermatozoa genomic DNA with no proteins added.

of this microhereterogeneity. Furthermore, a band with lower mobility with respect to PL-II that corresponds to H1 histone (Ausiò, 1986) is evident as well. Also, in this case we observed that the major alterations were found in the sample pertaining to the exposure to $1.5 \mu \mathrm{M}$ $\mathrm{CdCl}_{2}$, which showed a fraction of the sample of PL in an aggregated form to be in a major amount with respect to the samples relative to 5 and $10 \mu \mathrm{M} \mathrm{CdCl}_{2}$ exposure For this reason, in the subsequent analyses shown in Figs. 5 and 7, we used only the sample relative to the exposure to $1.5 \mu \mathrm{M} \mathrm{CdCl}$.

Figure 5 shows a comparative analysis of the electrophoretic pattern of Mytilus galloprovincialis PLs extracted from spermatozoa of mussels from Bagnoli biofouling panel in comparison to those of unexposed mussels derived from the reference site, and those of mussels exposed to $1.5 \mu \mathrm{M} \mathrm{CdCl}$ in laboratory tanks. Electrophoretic analyses were performed by both, AU-PAGE (Fig. 5 left) and by SDS-PAGE (Fig. 5 right). Both, AUPAGE and SDS-PAGE, showed that PL-proteins (PLII, PL-III and PL-IV) extracted from Bagnoli biofouling 
Cd polluted site

Reference site

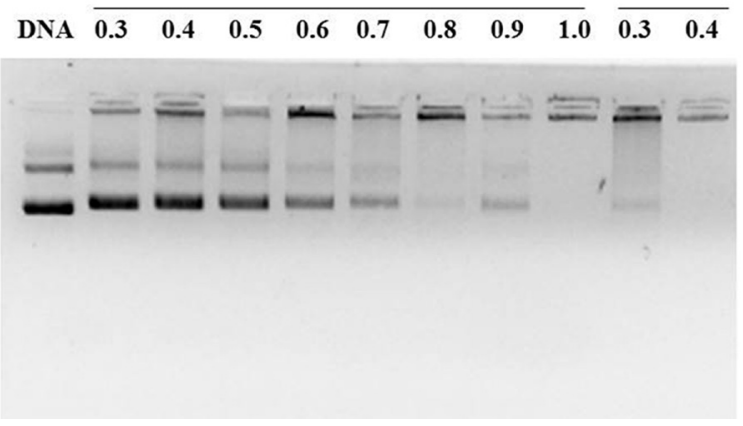

Figure 8. EMSA analyses of DNA binding affinity of PL-proteins from reference site and $\mathrm{Cd}$ polluted site mussels using pGEM3 DNA plasmid

EMSA analyses of DNA binding affinity of PL proteins from Mytilus galloprovincialis from Capo Miseno, reference site, and Bagnoli, $\mathrm{Cd}$ polluted site. Numbers on the wells indicate the PL-proteins/DNA (w/w) ratios used; DNA denotes Mytilus galloprovincialis pGEM3 DNA plasmid DNA with no proteins added.

panel mussels were completely in an aggregated form (lane 3) when compared to those extracted from unexposed mussels derived from the reference site (lane 1), while those derived from exposition of mussels to 1.5 $\mu \mathrm{M} \mathrm{CdCl}{ }_{2}$ in a laboratory tank appeared only in part in an aggregated form (lane 2). In Fig. 6 we analyzed the corresponding DNA binding affinity of the PL-proteins shown in Fig. 5 by EMSA. For these assays we used sperm genomic DNA extracted from the reference site mussel spermatozoa. The results indicated a decrease in the protein-DNA binding affinity of the PL-proteins extracted from mussels from the Bagnoli biofouling polluted site compared to those derived from the reference site. This conclusion derives from the observation that the saturation of DNA (i.e. when DNA is all close to the well) was reached at PL-proteins/DNA ratio of 4 instead of 1.5. We also analyzed the DNA binding affinity of the PL-proteins extracted from spermatozoa from Capo Miseno biofouling mussels exposed in laboratory tanks for $24 \mathrm{~h}$ to $1.5 \mu \mathrm{M} \mathrm{CdCl}$. Figure 7 shows the results obtained by EMSA and in this case, for the effect of mussels to cadmium exposure, a decreased DNA binding affinity of PL-proteins was also observed. The DNA binding affinity of these PL-proteins was decreased to the same extent as that observed for Bagnoli, Cd polluted site, biofouling PL-proteins since in this case DNA saturation is also reached at a PL-proteins/ DNA ratio of 4 .

In order to improve EMSA resolution, we performed the same EMSA experiments using pGEM3 DNA plasmid as a probe, under the same conditions as described in Vassalli and coworkers (Vassalli et al., 2015). In this case, we analyzed the PL-proteins extracted from spermatozoa of mussels after 5 and $10 \mu \mathrm{M} \mathrm{CdCl}$ exposure in order to verify that PL-proteins extracted from spermatozoa of mussels after $1.5 \mu \mathrm{M} \mathrm{CdCl}_{2}$ exposure had less DNA binding affinity when compared to those obtained after 5 and $10 \mu \mathrm{M} \mathrm{CdCl}_{2}$ exposure. We also found that Bagnoli PL-proteins showed a lower DNA binding affinity with respect to the Miseno reference site PL-proteins; in fact, DNA saturation occurred at a PL-proteins /DNA ratio of 1 and not at the Miseno reference site 0.4 ratio (Fig. 8). With regards to EMSA and PL-proteins obtained from mussels after cadmium exposure in laboratory tanks, we found a lower DNA binding affinity for PL-proteins obtained from spermatozoa of
A

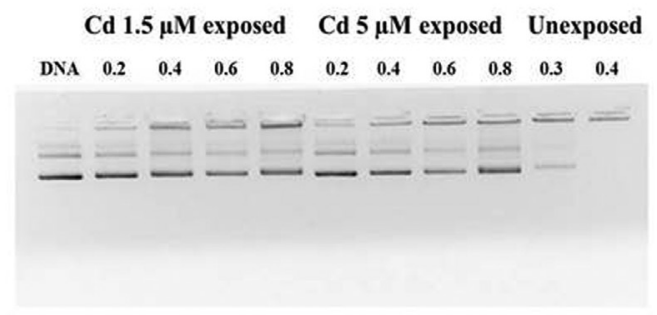

B

Cd $1.5 \mu \mathrm{M}$ exposed Cd $5 \mu \mathrm{M}$ exposed Unexposed
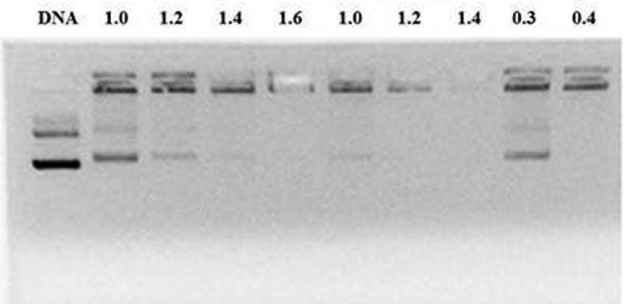

Cd $10 \mu \mathrm{M}$ exposed Unexposed

C

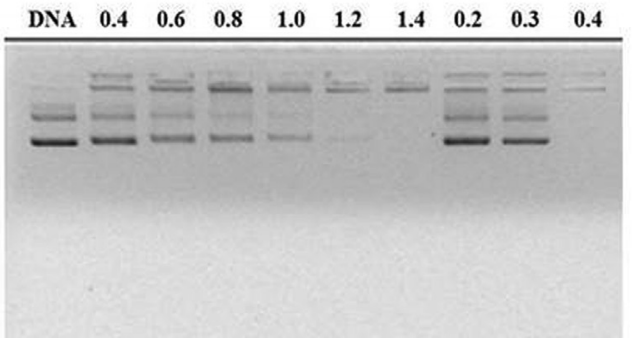

Figure 9. EMSA analyses of DNA binding affinity of PL-proteins from unexposed and 1.5, 5 and $10 \mu \mathrm{M} \mathrm{CdCl}_{2}$ exposed mussels using pGEM3 DNA plasmid

EMSA analysis of DNA binding affinity of PL-proteins from Mytilus galloprovincialis spermatozoa unexposed and exposed to 1.5, 5 (panels A and B) and 10 (panel C) $\mu \mathrm{M} \mathrm{CdCl}$. Numbers on the wells indicate the PL protein/DNA ( $\mathrm{w} / \mathrm{w}$ ) ratios used; DNA denotes Mytilus galloprovincialis pGEM3 DNA plasmid with no proteins added.

mussels exposed to all $\mathrm{CdCl}_{2}$ concentrations tested when compared to unexposed PL-proteins. In particular, while DNA saturation occurred at $0.4 \mathrm{PL} / \mathrm{DNA}$ ratio for the unexposed PL-proteins, DNA saturation occurred at ratios of 1.6 (Fig. 9B), 1.2 (Fig. 9 B), and 1.4 (Fig. 9C) after exposure to $1.5,5$ and $10 \mu \mathrm{M} \mathrm{CdCl}$, respectively.

The results shown in Fig. 9 confirm that the PL-proteins that present more alterations in terms of DNA binding affinity were those obtained after $1.5 \mu \mathrm{M} \mathrm{C \textrm {Cl } _ { 2 }}$ exposure.

When a totally aggregated form of PL-proteins from mussels from the Cd polluted site, Bagnoli site were tested by EMSA with sperm genomic DNA, a decreased DNA binding affinity was observed similar to that shown by the PL-proteins isolated from mussels exposed to $1.5 \mu \mathrm{M} \mathrm{CdCl}$; also, if only a fraction of these latter were in aggregate form. Furthermore, we observed that the DNA binding mode of these PL-proteins resulted in an "all or nothing mode" which we previously reported for sperm H1 histones (Piscopo et al., 2006; Piscopo et al., 2010), for Chaetopterus variopedatus CvPL (Piscopo et al., 1993; Fioretti et al., 2012) and for PL-III (Vassalli et al., 2015) using pGEM3 DNA plasmid (Carbone et al., 2012). According to this DNA binding mode, a fraction of DNA has electrophoretic mobility similar to that of the naked DNA, while at increasing PL/DNA ratios the DNA fraction in an aggregated form migrates close to 
the well. These results indicate that xenobiotics present in the Cd polluted area of Bagnoli could alter the sperm chromatin condensation and fertilizing capacity of Mytilus galloprovincialis by reducing the DNA binding affinity of PL-proteins, and consequently affect its reproductive fitness. Overall, the results obtained show that cadmium,

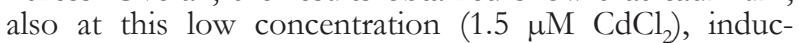
es the same decrease in DNA binding affinity by PLproteins extracted from spermatozoa of mussels from Bagnoli, Cd polluted site, despite the fact that it causes only a fraction of PL-proteins to form aggregates (Fig. 5 lane 2). In experiments performed in our laboratories at this time, we have found that an exposure of mussels to $5 \mu \mathrm{M} \mathrm{CdCl}{ }_{2}$ causes a change in the PL-protein PL-II DNA binding mode from "intermediate form" to "all or nothing" (manuscript in preparation). "Intermediate form" is a DNA-binding mode which implies that the DNA band has a progressive mobility decrease at increasing PL/ DNA ratios, as we previously reported for somatic H1 histone (Piscopo et al., 2010), and for PL-II and PL-IV (Vassalli et al., 2015) using pGEM3 DNA plasmid (Carbone et al., 2012). Chromatin condensation and DNA affinity may provide important indices of sperm quality and the reduced DNA affinity of PL-proteins found for those extracted from spermatozoa of the Cd polluted site and in those from mussels exposed to cadmium in laboratory tanks is in line with what has been shown for human protamine HP2 for the effects of lead (Quintanilla-Vega et al., 2000) and also with our recent work (Piscopo et al., 2018b). It has been reported that cadmium can inhibit chromatin condensation which is required for proper sperm maturation and in doing so leads to infertility in male mice (Monsefi et al., 2010). Hence, our findings not only provide new insights into cadmiuminduced alterations of testis and sperm proteins but with these new and easy approaches, using spermatozoa PLs, we can obtain useful information for heavy metal impact assessment and species management.

\section{CONCLUSION}

In this work we have monitored Bagnoli industrial pollution using biofouling mussel from a Conatex panel after one year of exposition, and followed cadmium effects on its reproductive health using both, standard and innovative biotechniques. The results demonstrate: a high cadmium bioaccumulation in Bagnoli biofouling mussel testes; a positive correlation between cadmium concentration in the mussel testes and $m t 20$ expression in the range of $1.5-10 \mu \mathrm{M} \mathrm{CdCl}$ in exposed mussels ; a totally aggregated form of PL of mussels from the Cd polluted site, Bagnoli, and a decreased DNA binding affinity in mussels exposed to $\mathrm{CdCl}_{2}$; and by $\mathrm{PL}$ analyses, new insights to managing cadmium toxicity and, hopefully, mussel sustainability.

\section{Declaration of conflicting interest}

The authors declare that there is no conflict of interest.

\section{Acknowledgments}

The authors want to thank the Interdepartmental Research Center for Environment (I.R.C.Env.), Federico II University, Napoli, Italy for the logistic help and Dr. Gianluca Notariale for his technical contribution.

\section{Acknowledgments of Financial Support}

This work was performed with departmental funds number: 000020--PRD-2017-M-PISCOPO_001_001 awarded to Marina Piscopo (Department of Biology; University of Napoli Federico II; Italy)

\section{REFERENCES}

Amiard JC, Amiard-Triquet C, Barka S, Pellerin J, Rainbow PS (2006) Metallothioneins in aquatic invertebrates: Their role in metal detoxification and their use as biomarkers. Aquat Toxicol 76: 160-202. https://doi.org/10.1016/j.aquatox.2005.08.015

Ausió J, Subirana JA (1982) A high molecular weight nuclear basic protein from the bivalve mollusc Spisula solidissima. I Biol Chem 25: 2802-2805. http://dx.doi.org/10.1021/bi0360455

Ausiò J (1986) Structural variability and compositional homology of the protamine-like components of the sperm from the bivalve mollusks. Comp Biochem Physiol 85B: 439-449

Ausiò J, McParland R (1989) Sequence and characterization of the sperm-specific protein from Mytilus calijiornianus. Eur J Biochem 182: 569-576. http://dx.doi.org/10.1111/j.1432-1033.1989.tb14865.x

Bartiromo A, Guignard G, Barone Lumaga MR, Barattolo F, Chiodini $G$, Avino R, Guerriero G, Barale G (2013) The cuticle micromorphology of in situ Erica arborea L. exposed to long-term volcanic gases. Environ Exp Botany 87: 197-206. http://doi.org/10.1016/j. envexpbot.2012.10.006

Basile A, Loppi S, Piscopo M, Paoli L, Vannini A, Monaci F, Sorbo S, Lentini M, Esposito S (2017) The biological response chain to pollution: a case study from the "Italian Triangle of Death" assessed with the liverwort Lunularia cruciata. Environ Sci Pollut Res. http://doi. org/10.1007/s11356-017-9304-y.

Brady JP, Ayoko GA, Martens WN, Goonetilleke A (2015) Development of a hybrid pollution index for heavy metals in marine and estuarine sediments. Environ Monit Assess 187: 306. http://doi. org/10.1007/s10661-015-4563-x

Carbone A, Fioretti FM, Fucci L, Ausiò J, Piscopo M (2012) High efficiency method to obtain supercoiled DNA with a commercial plasmid purification kit. Acta Biochim Polon 59: 275-278

Conte B, Sorbo S, Piscopo M, Rabbito D, De Ruberto F, Guerriero G, Basile A (2017) Antioxidant activity and ultrastructural alterations in the biosensor Lemna minor $L$. exposed in bags in Sarno river (South Italy). Fresenius Environmental Bulletin 26: 225-236

De Franciscis P, Ianniello R, Labriola D, Ambrosio D, Vagnetti P, Mainini G, Trotta C, Mele D, Campitiello MR, Caprio F (2015) Environmental pollution due to cadmium: measure of semen quality as a marker of exposure and correlation with reproductive potential. Clin Exp Obstet Gynecol 42: 767-770. PMID: 26753482

De Maio A, Trocchia S, Guerriero G (2014) The amphibian Pelophylax bergeri (Günther, 1986) testis poly(ADP-ribose)polymerases: relationship to endocrine disruptors during spermatogenesis. Ital J Zool 81: 256-263. http://doi.org/10.1080/11250003.2014.902124

Dondero F, Piacentini L, Banni M, Rebelo M, Burlando B, Viarengo A (2005) Quantitative PCR analysis of two molluscan metallothionein genes unveils differential expression and regulation. Gene 345: 259270. http://doi.org/10.1016/ j.gene.2004.11.031.

Fasulo S, Guerriero G, Cappello S, Colasanti M, Schettino T, Leonzio C, Mancini G, Gornati R (2015) The "SYSTEMS BIOLOGY" in the study of xenobiotic effects on marine organisms for evaluation of the environmental health status: biotechnological applications for potential recovery. Rev Environ Sci Biotechnol 14: 339-345. http://doi. org/ 10.1007/s11157-015-9373-7

Fioretti FM, Febbraio F, Carbone A, Branno M, Carratore V, Fucci L, Ausió J, Piscopo M (2012) A sperm nuclear basic protein from the sperm of the marine worm Chaetopterus variopedatus with sequence similarity to the arginine-rich C-termini of chordate protamine-likes. DNA Cell Biol 31: 1392-1402. http://doi.org/10.1089/ dna.2011.1547

Guerriero G, Di Finizio A, Ciarcia G (2003) Oxidative Defenses in the Sea Bass, Dicentrarchus labrax. In Handbook of Oxygen Transport to Tissue XXIV. Advances in Experimental Medicine and Biology, Dunn JF, Swartz HM, eds, 530: 681-688. Springer. http://doi. org/10.1007/978-1-4615-0075-9_68

Guerriero G, Prins GS, Birch L, Ciarcia G (2005) Neurodistribution of androgen receptor immunoreactivity in the male frog, Rana esculenta. Ann N Y Acad Sci 1040: 332-336. http://doi.org/10.1196/ annals. 1327.054

Guerriero G, Ciarcia G (2006) Biomarkers of stress and reproduction in fish. In Fish Endocrinology, Reinecke M, Zaccone G, Kapoor BG, eds, pp 665-692. Enfield (NH), USA; Plymouth, UK: Sci Publ Inc2. http://doi.org/10.1201/b10745-29

Guerriero G (2009) Vertebrate sex steroid receptors: evolution, ligands, and neurodistribution. Ann N Y Acad Sci 1163: 154-168. http://doi. org/10.1111/j.1749-6632.2009.04460.x 
Guerriero G, Trocchia S, Abdel-Gawad FKh, Ciarcia G (2014) Roles of reactive oxygen species in the spermatogenesis regulation. Front Endocrinol 5: 56. http://doi.org/10.3389/fendo.2014.00056

Guerriero G, D’Errico G, Di Giaimo R, Rabbito D, Olanrewaju OS, Ciarcia G (2017) Reactive oxygen species and glutathione antioxidants in the testis of the soil biosentinel Podarcis sicula (Rafinesque 1810). Environ Sci Pollut Res. http://doi.org/ 10.1007/s11356-0170098-8

Han HL, Sheng Z, Liu GD, Long LL, Wang YF, Yang WX, Zhu JQ, (2015) Cloning, characterization and cadmium inducibility of metallothionein in the testes of the mudskipper Boleophthalmus pectinirostris. Ecotoxicol Environ Saf 119: 1-8. http://doi.org/10.1016/j. ecoenv.2015.04.055

Hardivillier A, Leignel V, Denis F, Uguen G, Cosson R, Laulier M (2004) Do organisms living around hydrothermal vent sites contain specific metallothioneins? The case of the genus Batbymodiolus (Bivalvia, Mytilidae). Comp Biochem Physiol C-Pharmacol Toxicol Endocrinol 139: 111-118. http://doi.org/10.1016/j.cca.2004.09.012

Hsiao CJ, Stapleton SR (2009) Early sensing and gene expression profiling under a low dose of cadmium exposure. Biochimie 91: 329-343. http://doi.org/ 10.1016/j.biochi.2008.10.006

Jurasović J, Cvitković P, Pizent A, Čolak B, Telišman S (2004) Semen quality and reproductive endocrine function with regard to blood cadmium in Croatian male subject. BioMetals 17: 735-743

Kalman J, Riba I, Del Valls T, Blasco J (2010) Comparative toxicity of cadmium in the commercial fish species Sparus aurata and Solea senegalensis. Ecotoxicol Environ Saf 73: 306-311 http://doi.org/10.1016/j. ecoenv.2009.10.013

Ladhar-Chaabouni R, Machreki-Ajmi M, Hamza-Chaffai A (2012) Use of metallothioneins as biomarkers for environmental quality assessment in the Gulf of Gabès (Tunisia). Environ Monit Assess 184: 2177-2192. http://doi.org/ 10.1007/s10661-011-2108-5

Li N, Hou YH, Ma DD, Jing WX, Dahms HU, Wang L (2015) Lead accumulation, oxidative damage and histopathological alteration in testes and accessory glands of freshwater crab, Sinopotamon benanense, induced by acute lead exposure. Ecotoxicol Environ Saf 117: 20-27. http://doi.org/10.1016/j.ecoenv.2015.03.019

Livak KJ, Schmittgen TD (2001) Analysis of relative gene expression data using real-time quantitative PCR and the 2(-Delta Delta C (T)). Methods 25: 402-408. http://doi.org/10.1006/meth.2001.1262

Mackey EA, Overnell J, Dunbar B, Davidson I, Hunziker PE, Kagi JH, Fothergill JE (1993) Complete amino acid sequences of five dimeric and four monomeric forms of metallothionein from the edible mussel Mytilus edulis. Eur J Biochem 218: 183-194. http://doi. org/10.1111/j.1432-1033.1993.tb18364.x

Mathur N, Pamdey G, Jain GC (2010) Male reproductive toxicity of some selected metals: A review. J Biol Sci 10: 396-404. http://doi. org/10.3923/jbs.2010.396.404

Monsefi M, Alaee S, Moradshahi A, Rohani L (2010) Cadmium-induced infertility in male mice. Environ Toxicol 25: 94-102. http:// doi.org/10.1002/tox.20468

Piscopo M, Tomei L, De Petrocellis L, Geraci G (1993). Anion-mediated lysine-arginine interaction. Evidence in Chaetopterus variopedatus sperm protamine. FEBS Lett 334: 125-127. ISSN: 0014-5793

Piscopo M, De Petrocellis L, Conte M, Pulcrano G, Geraci G (2006). On the possibility that $\mathrm{H} 1$ histone interaction with DNA occurs through phosphates connecting lysine and arginine side chain groups. Acta Biochim Polon 53: 507-513. ISSN: 0001-527X

Piscopo M, Conte M, Di Paola F, Conforti S, Rana G, De Petrocellis L, Fucci L, Geraci G (2010) Relevance of Arginines in the Mode of Binding of H1 Histones to DNA. DNA Cell Biol 29: 339-347. http://doi.org/10.1089/dna.2009.0993

Piscopo M, Ricciardiello M, Palumbo G, Troisi J (2016) Selectivity of metal bioaccumulation and its relationship with glutathione S-transferase levels in gonadal and gill tissues of Mytilus galloprovincialis exposed to Ni (II), Cu (II) and Cd (II). Rendiconti Lincei. Scienze Fisiche e Naturali 27: 1-12. http://doi.org/ 10.1007/s12210-016-0564-02 2015

Piscopo M, Notariale R, Troisi J (2017) hsp70 as new cadmium bioaccumulation marker to prevent the risks of mussels consumption in human nutrition. Madridge J Clin Res 1: 39-45 doi: 10.18689/ mjcr.2017-107

Piscopo M, Trifuoggi M, Scarano C, Gori C, Giarra A, Febbraio F (2018a) Relevance of arginine residues in $\mathrm{Cu}(\mathrm{II})$-induced DNA breakage and Proteinase $\mathrm{K}$ resistance of $\mathrm{H} 1$ histones. Sci Rep 8: 7414. doi: 10.1038/s41598-018-25784-z.

Piscopo M, Notariale R, Rabbito D, Ausió J, Olanrewaju OS, Guerriero $G$ (2018b) Mytilus galloprovincialis (Lamarck, 1819) spermatozoa: hsp70 expression and protamine-like protein property studies. Environ Sci Pollut Res Int 25: 12957-12966. doi: 10.1007/s11356-0181570-9

Quintanilla-Vega B, Hoover DJ, Bal W, Silbergeld EK, Waalkes MP, Anderson LD (2000) Lead interaction with human protamine (HP2) as a mechanism of male reproductive toxicity. Chem Res Toxicol 13: 594-600. http://doi.org/10.1021/tx000017v

Rave N, Crkvenjakov R, Boedtker H (1979) Identification of procollagen mRNAs transferred to diazobenzyloxymethyl paper from formaldehyde agarose gels. Nucleic Acids Res 6: 3559-3567

Rzymski P, Tomczyk K, Rzymski P, Poniedziałek B, Opala T, Wilczak M (2015) Impact of heavy metals on the female reproductive system. Ann Agric Environ Med 22: 259-264. http://doi. org/10.5604/12321966.1152077

Salvati D, Conforti S, Conte MC, Matassa DS, Fucci L, Piscopo M (2008) Self-association of H1 histones. Relevance of arginine content and possible functional role. Acta Biochim Polon 55: 701-706

Scalici M, Traversetti L, Spani F, Malafoglia V, Colamartino Persichini T, Cappello S, Mancini G, Guerriero G, Colasanti M (2017) Shell fluctuating asymmetry in the sea-dwelling benthic bivalve Mytilus galloprovincialis (Lamarck, 1819) as morphologicalmarkers to detect environmental chemical contamination. Ecotoxicology 26: 396-404. https://doi.org/10.1007/s10646-017-1772-9

Selevan SG, Borkovec L, Slott VL, Zudova Z, Rubes J, Evenson DP, Perreault SD (2000) Semen quality and reproductive health of young Czech men exposed to seasonal air pollution. Environ Health Perspect 108: 887-894

Sheng Z, Yang WX, Zhu JQ (2015) Metallothionein from Pseudosciaena crocea: expression and response to cadmium-induced injury in the testes. Ecotoxicology 24: 779-794. http://doi.org/10.1007/s10646$015-1423-y$

Simoniello P, Filosa S, Scudiero R, Trinchella F, Motta MC (2013) Cadmium impairment of reproduction in the female wall lizard $\mathrm{P}_{0}$ darcis sicula. Inc Environ Toxicol 28: 553-562. http://doi.org/10.1002 / tox.20749

Skibinski DO, Gallagher C, Beynon CM (1994) Sex-limited mitochondrial DNA transmission in the marine mussel Mytilus edulis. Genetics 138: 801-809. http://doi.org/ PMC1206229

Spitsbergen JM, Kent ML (2003) The state of the art of the zebrafish model for toxicology and toxicologic pathology research-advantages and current limitations. Toxicol Pathol 31: 62-87. http://doi. org $/ 10,1080 / 01926230390174959$

Sureda A, Box A, Tejada S, Blanco A, Caixach J, Deudero S (2011) Biochemical responses of Mytilus galloprovincialis as biomarkers of acute environmental pollution caused by the Don Pedro oil spill (Eivissa Island, Spain). Aquat Toxicol 101: 540-549. http://doi.org/10.1016/j. aquatox.2010.12.011

Thompson J, Bannigan J (2008) Cadmium: toxic effects on the reproductive system and the embryo. Reprod Toxicol 25: 304-315. http:// doi.org/ 10.1016/j.reprotox.2008.02.001

Vassalli QA, Caccavale F, Avagnano S, Murolo A, Guerriero G, Fucci L, Ausió J, Piscopo M (2015) New insights into protaminelike component organization in Mytilus galloprovincialis' sperm chromatin. DNA Cell Biol 34: 162-169. http://dx.doi.org/10.1089/ dna.2014.2631

Vergani L, Grattarola M, Grasselli E, Dondero F, Viarengo A (2007) Molecular characterization and function analysis of MT-10 and MT20 metallothionein isoforms from Mytilus galloprovincialis. Arch Biochem Biophys 465: 247-253. http://doi.org/ 10.1016/ j.abb.2007.05.023

Vincent-Hubert F, Châtel A, Gourlay-Francé C (2014) Metallothionein mRNA induction is correlated with the decrease of DNA strand breaks in cadmium exposed zebra mussels. Mutat Res Genet Toxicol Environ Mutagen 766: 10-15. http://doi.org/ 10.1016/j.mrgentox.2014.03.006

Wirth JJ, Mijal RS (2010) Adverse effects of low level heavy metal exposure on male reproductive function. Syst Biol Reprod Med 56: 147 167. http://doi.org/ 10.3109/19396360903582216 